\title{
Importance of ice algal production for top predators: new insights using sea-ice biomarkers
}

\author{
A. Goutte ${ }^{1,2, *}$, J.-B. Charrassin ${ }^{1}$, Y. Cherel ${ }^{2}$, A. Carravieri ${ }^{2}$, S. De Grissac ${ }^{2}$, G. Massé ${ }^{1,3}$ \\ ${ }^{1}$ LOCEAN/IPSL - UMR 7159 Centre National de la Recherche Scientifique/Université Pierre et Marie Curie/ \\ Institut de Recherche pour le Développement/Museum National d'Histoire Naturelle, 75005 Paris, France \\ ${ }^{2}$ Centre d'Etudes Biologiques de Chizé, Centre National de la Recherche Scientifique, UPR 1934, 79360 Beauvoir sur Niort, \\ France \\ ${ }^{3}$ Centre National de la Recherche Scientifique and Université Laval, UMI 3376, Takuvik, Québec G1V 0A6, Canada
}

\begin{abstract}
Antarctic seals and seabirds are strongly dependent on sea-ice cover to complete their life history. In polar ecosystems, sea ice provides a habitat for ice-associated diatoms that ensures a substantial production of organic matter. Recent studies have presented the potential of highly branched isoprenoids (HBIs) for tracing carbon flows from ice algae to higher-trophic-level organisms. However, to our knowledge, this new method has never been applied to sub-Antarctic species and Antarctic seals. Moreover, seasonal variations in HBI levels have never been investigated in Antarctic predators, despite a likely shift in food source from ice-derived to pelagic organic matter after sea-ice retreat. In the present study, we described HBI levels in a community of seabirds and seals breeding in Adélie Land, Antarctica. We then validated that sub-Antarctic seabirds had lower levels of diene, a HBI of sea-ice diatom origin, and higher levels of triene, a HBI of phytoplanktonic origin, compared with Antarctic seabirds. Finally, we explored temporal changes in HBI levels after the ice break up in summer. The level of diene relative to triene in Adélie penguin chicks increased and then declined during the breeding season, which was consistent with the short and intense proliferation of sea-ice algae in spring, followed by the pelagic phytoplankton bloom in summer. HBI biomarkers in Antarctic seabirds and seals thus indicate a shift from ice-algal derived organic matter to a pelagic carbon source during the summer breeding season.
\end{abstract}

KEY WORDS: Ice proxy $\cdot$ Penguin $\cdot$ Petrel $\cdot$ Pinniped $\cdot$ Southern Ocean

\section{INTRODUCTION}

Antarctic top predators, such as seals and seabirds, are strongly dependent on sea-ice cover to complete their life history (Barbraud \& Weimerskirch 2001, Siniff et al. 2008, Forcada et al. 2012). Indeed, sea ice provides a habitat for ice-associated diatoms (Lizotte 2001) that are then grazed by pivotal species for top predators, such as the Antarctic krill Euphausia superba (Quetin \& Ross 2001, Nicol 2006) and the Antarctic silverfish Pleuragramma antarcticum in its early stages (Giraldo et al. 2011, La Mesa \& Eastman 2012). The summer ice melt also triggers the prolifer- ation of pelagic phytoplankton, another source of primary production (Arrigo et al. 1997). Hence, one may predict that the relative contribution of ice-derived organic matter for Antarctic top predators reaches a peak in late spring and early summer. However, this seasonal shift in carbon source has been poorly investigated due to the lack of appropriate and specific ice proxies.

A new set of diatom markers known as highly branched isoprenoids (HBIs) could be good candidates for evaluating the seasonal importance of ice algal-derived organic matter in polar marine consumers (Brown et al. 2013a,b, Goutte et al. 2013). HBI 
isomers are synthesized by a limited number of diatom species and have been used as fingerprints of ice-covered versus open waters (Belt et al. 2007, Massé et al. 2011). $\mathrm{IP}_{25}$ (ice proxy with 25 carbon atoms) has been shown to be specifically produced by Arctic sea-ice diatoms (Belt et al. 2007). In the Antarctic, diene has been isolated in sea-ice diatom communities, but not in pelagic phytoplankton (e.g. Sinninghe Damsté et al. 2007, Massé et al. 2011). Moreover the stable isotopic composition of diene $\left(\delta^{13} \mathrm{C}\right.$ values of -8.5 and $-5.7 \%$ in Antarctic sea-ice samples and -9.1 and $-9.4 \%$ in sediments; Sinninghe Damsté et al. 2007, Massé et al. 2011) is consistent with its sea-ice origin. Triene has been detected in phytoplankton samples in open ocean and at the sea-ice edge in Antarctica, but was absent in sea-ice diatom samples (e.g. Massé et al. 2011). Furthermore, the stable isotopic composition of triene $\left(\delta^{13} \mathrm{C}\right.$ value of $-40 \%$; Massé et al. 2011) supports its phytoplanktonic origin.

HBI markers have been shown to be transferred from diatoms to top predators (Brown et al. 2013a,b, Goutte et al. 2013). Most studies have focused on the use of $\mathrm{IP}_{25}$ in Arctic animals (Brown \& Belt 2012a,b, Brown et al. 2013a,b) and only 2 HBI studies have been conducted for Antarctic consumers (Goutte et al. 2013, 2014). Diene/triene ratios (hereafter D/T ratios) have been suggested to reflect the relative contribution of ice-associated organic matter to the diet of Antarctic predators (Goutte et al. 2013, 2014). However, to our knowledge, there is no report of HBI levels in sub-Antarctic animals and Antarctic seals. Moreover, seasonal variations in HBI levels during the short summer breeding period have never been documented, despite a likely shift in carbon source from ice-derived to pelagic organic matter in Antarctic seals and seabirds. The present study reports new evidences of the use of HBI markers for studying the importance of ice-derived carbon flow in Antarctic predators. Our first aim was to describe HBI levels in the liver or egg of Antarctic top predators (Adélie penguin Pygoscelis adeliae, emperor penguin $A p$ tenodytes forsteri, snow petrel Pagodroma nivea, cape petrel Daption capense, Wilson's storm petrel Oceanites oceanicus, Antarctic fulmar Fulmarus glacialoides, south polar skua Catharacta maccormicki, and Weddell seal Leptonychotes weddelli). Second, we validated that sub-Antarctic species showed lower D/T ratios than Antarctic species. To do so, we compared HBI levels in the stomach oil of the blue petrel Halobaena caerulea breeding in Kerguelen Islands and of the snow petrel breeding in Adélie Land, Antarctica. Third, we explored temporal changes in
HBI levels during the breeding period of Weddell seals, Adélie penguin chicks, and snow petrels. We predicted an increase in the $\mathrm{D} / \mathrm{T}$ ratio corresponding to the proliferation of sea ice-algae in spring and early summer, and then a decrease in the $\mathrm{D} / \mathrm{T}$ ratio as a result of pelagic phytoplankton blooms.

\section{MATERIALS AND METHODS}

\section{Study site and species}

Table 1 summarizes the samples collected in the Pointe Géologie Archipelago $\left(66^{\circ} 40^{\prime} \mathrm{S}, 140^{\circ} 01^{\prime} \mathrm{E}\right)$, Adélie Land, Antarctica and on Mayes Island $\left(48^{\circ} 28^{\prime} \mathrm{S}\right.$, $69^{\circ} 57^{\prime} \mathrm{E}$ ), in the Kerguelen Archipelago, Antarctica. Concerning Weddell seals in Adélie Land, one male adult was found dead on the sea ice on 11 October 2011 and a liver sample was excised by a veterinary surgeon. In addition, 9 adult females (body length, mean \pm SE: $235.3 \pm 3.9 \mathrm{~cm}$; body weight: $356.2 \pm$ $20.1 \mathrm{~kg}$ ) and 7 subadults (4 females and 3 males, body length: $179.0 \pm 6.5 \mathrm{~cm}$ ) were captured for blubber biopsy sampling in mid-November and in midJanuary, respectively (Table 1 ). The seals were approached on the sea ice on foot and temporarily restrained with a head bag or pole net. Full-depth blubber biopsies were obtained with a sterile $6 \mathrm{~mm}$ disposable biopsy punch from a cleansed (betadine and isopropyl alcohol) site $20 \mathrm{~cm}$ lateral to the spinal column and anterior to the pelvis. Each sample was immediately wrapped in aluminum foil and placed in a cooler containing snow for transport from the field. The outer layer was not separated from the inner layer of the blubber, since HBI analyses require a substantial amount of tissue ( $\sim 0.2 \mathrm{~g}$ dry weight).

Petrels store oil from dietary origin in their stomach and the biochemical composition of oil has been used previously as an efficient tool in trophic studies using fatty acids and fatty alcohols (Connan et al. 2008). Stomach oils were collected from 13 adult blue petrels in Mayes Island during chick rearing and from 45 snow petrels in Adélie Land during 4 breeding stages $(\mathrm{N}=12$ adults during the pre-laying period, 25 November $2011 ; \mathrm{N}=12$ adults during the early incubation period, 25 December 2011; N = 12 adults during the late incubation period, 13 January 2012; $\mathrm{N}=9$ chicks during the chick-rearing period, 13 February 2012, Table 1). Moreover many eggs did not hatch and chicks' mortality was high because of the harsh environmental conditions during the 20112012 breeding season in the Pointe Géologie Archipelago. Unhatched eggs were collected and liver 
Table 1. Samples collected with species and status (adult or chick), sampling period, tissue, sample size (N), levels of diene and triene (expressed in $\mathrm{ng} \mathrm{g}^{-1}$ relative to the internal standard) and diene/triene $(\mathrm{D} / \mathrm{T})$ ratios (mean $\pm \mathrm{SE}$ )

\begin{tabular}{|lcccccc|}
\hline Species and status & Sampling period & Tissue & N & Diene & Triene & D/T ratio \\
\hline Weddell seal, adult & 11 Oct 2011 & Liver & 1 & 106.89 & 197.28 & 0.542 \\
Weddell seal, adult & 08-17 Nov 2011 & Blubber & 9 & $0.61 \pm 0.11$ & $2.62 \pm 0.36$ & $0.220 \pm 0.015$ \\
Weddell seal, subadult & 11-18 Jan 2012 & Blubber & 7 & $0.09 \pm 0.06$ & $1.58 \pm 0.18$ & $0.064 \pm 0.043$ \\
Blue petrel, adult & 30 Jan 2012 & Stomach oil & 13 & $1.59 \pm 0.36$ & $429.03 \pm 88.97$ & $0.005 \pm 0.001$ \\
Snow petrel, adult & 25 Nov 2011-13 Feb 2012 & Stomach oil & 45 & $12.94 \pm 2.54$ & $153.41 \pm 23.06$ & $0.086 \pm 0.016$ \\
Snow petrel & 17 Dec 2011-16 Jan 2012 & Egg & 23 & $0.45 \pm 0.06$ & $21.68 \pm 1.37$ & $0.022 \pm 0.003$ \\
Cape petrel & 17 Dec 2011-10 Jan 2012 & Egg & 3 & $0.20 \pm 0.11$ & $69.06 \pm 25.42$ & $0.005 \pm 0.003$ \\
Wilson's storm-petrel, adult & 15 Dec 2011 & Liver & 1 & 1.000 & 36.94 & 0.027 \\
Wilson's storm-petrel & 18-19 Jan 2012 & Egg & 2 & 0.61 & 5.92 & $0.104 \pm 0.006$ \\
Antarctic fulmar & 04 Jan 2012 & Egg & 1 & 0.29 & 6.24 & 0.046 \\
South polar skua, adult & 14 Dec 2011-01 Feb 2012 & Liver & 5 & $8.99 \pm 1.98$ & $24.01 \pm 2.76$ & $0.430 \pm 0.127$ \\
South polar skua & 23 Dec 2011 & Egg & 1 & 0.57 & 6.42 & 0.088 \\
Emperor penguin, adult & 05 Nov 2011 & Liver & 1 & 3.74 & 27.24 \\
Adélie penguin, adult & 16 Jan 2012-02 Feb 2012 & Liver & 7 & $9.94 \pm 3.48$ & $109.23 \pm 33.01$ & $0.119 \pm 0.046$ \\
Adélie penguin, chicks & 27 Dec 2011-25 Jan 2012 & Liver & 25 & $7.00 \pm 1.10$ & $30.83 \pm 3.74$ & $0.238 \pm 0.037$ \\
Adélie penguin & 21 Nov-06 Dec 2011 & Egg & 11 & $1.36 \pm 0.28$ & $42.40 \pm 5.99$ & $0.034 \pm 0.004$ \\
\hline
\end{tabular}

samples were excised on dead chicks and dead adults (Table 1). All samples were frozen within $2 \mathrm{~h}$ at $-80^{\circ} \mathrm{C}$ until analysis at the LOCEAN/IPSL (Paris, France) laboratory.

\section{HBI analysis}

HBI analyses were conducted as previously described in Goutte et al. (2013). Procedural blanks were analyzed for every 20 samples to ensure the absence of contamination.

\section{Statistical analysis}

All statistical tests were performed using R 2.15.2 (R Development Core Team, 2012). First, interspecies differences in HBI levels in the egg or liver were performed using Kruskal-Wallis rank sum tests and a pairwise Wilcoxon test with post hoc Bonferroni correction. Only species with $>2$ individuals were included in the tests. Second, we compared HBI levels in the stomach oil of adult snow petrels and adult blue petrels collected during the same period (January 2012), using Wilcoxon rank sum tests. Third, we explored whether HBI levels varied during the breeding period. In blubber biopsy samples of Weddell seals, Wilcoxon rank sum tests were performed to test whether HBI levels differed between November 2011 and January 2012. Kruskal-Wallis rank sum tests and a pairwise Wilcoxon test with post hoc Bonferroni correction were performed to test whether HBI levels in stomach oil of snow petrels and in liver samples of Adélie penguin chicks changed between the 4 time periods (4 breeding stages for snow petrels and the first $4 \mathrm{wk}$ after hatching for Adélie penguin chicks).

\section{RESULTS}

\section{HBI differences between Antarctic species}

In egg samples, intraspecies variations were extremely low, but $\mathrm{D} / \mathrm{T}$ ratios significantly differed among species (Kruskal-Wallis $\chi^{2}=13.125, p=0.001$, Fig. 1). Specifically, D/T ratios were 7 times higher in eggs of the Adélie penguin compared with the cape petrel; 1.5 times higher in the Adélie penguin compared with the snow petrel; and 4.5 times higher in the snow petrel compared with the cape petrel (pairwise Wilcoxon tests with Bonferroni corrections, $\mathrm{p}<0.04$ ).

In liver samples, $\mathrm{D} / \mathrm{T}$ ratios significantly differed among species (Kruskal-Wallis $\chi^{2}=6.108, p=0.047$, Fig. 1). Specifically, D/T ratios were 2 times lower in adult Adélie penguins compared with chicks and $>3.5$ times lower compared with south polar skuas (pairwise Wilcoxon tests with Bonferroni corrections, $\mathrm{p}<0.04)$.

\section{HBI differences between Antarctic and sub-Antarctic petrels}

In January 2012, the D/T ratio in the stomach oil of the snow petrel was $>17$ times higher than in the stomach oil of the blue petrel (Wilcoxon rank sum 


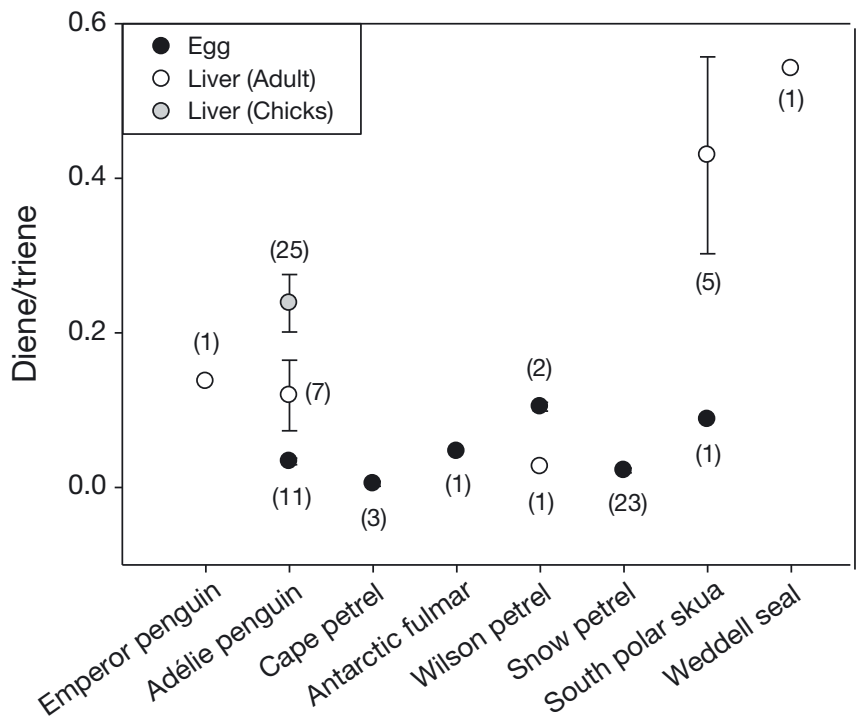

Fig. 1. Diene/triene ratio (mean $\pm \mathrm{SE}$ ) in the liver and egg of seabirds and seals breeding in Adélie Land, Antarctica. Sample sizes are denoted by numbers in brackets

tests, $\mathrm{W}=0, \mathrm{p}<0.001$, Fig. 2). Specifically, diene levels were 7 times higher in snow petrels compared with blue petrels $(\mathrm{W}=3, \mathrm{p}<0.001)$, whereas triene levels were 3 times higher in blue petrels compared with snow petrels $(\mathrm{W}=148, \mathrm{p}<0.001)$.

\section{Seasonal variations in HBI levels}

$\mathrm{D} / \mathrm{T}$ ratios in blubber of Weddell seals was 3.4 times higher in adults sampled in November than in

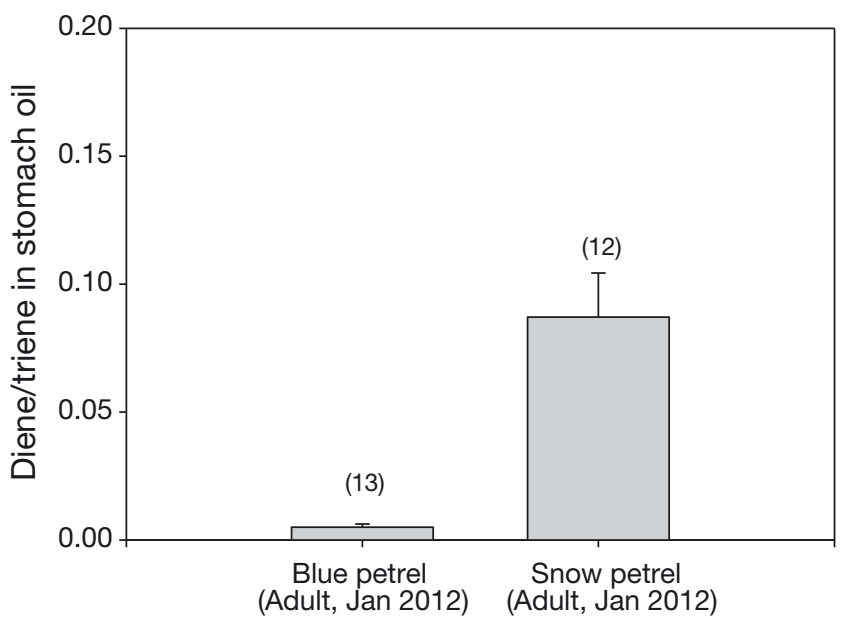

Fig. 2. Diene/triene ratio (mean $\pm \mathrm{SE}$ ) in the stomach oil of blue petrels (30 January 2012) breeding in the sub-Antarctic and of snow petrels (13 January 2012) breeding in the Antarctic. Sample sizes are denoted by numbers in brackets subadults sampled in January (Wilcoxon rank sum test, $\mathrm{W}=53, \mathrm{p}=0.024$, Fig. 3). Specifically, diene and triene levels were approximately 7 and 1.5 times higher in November compared with January, respectively $(\mathrm{W}=59, \mathrm{p}=0.004$ and $\mathrm{W}=53, \mathrm{p}=$ 0.023 , respectively). $\mathrm{D} / \mathrm{T}$ ratios in stomach oil of snow petrels did not significantly differ between the 4 breeding stages (Kruskal-Wallis $\chi^{2}=5.721, \mathrm{p}=$ $0.126)$, despite a trend towards higher $\mathrm{D} / \mathrm{T}$ ratios during the incubation period compared with the pre-laying and chick-rearing periods (Fig. 4). Diene and triene levels significantly differed between the 4 breeding stages (Kruskal-Wallis $\chi^{2}=18.973$, p < 0.001 and Kruskal-Wallis $\chi^{2}=22.704, \mathrm{p}<0.001$ ) with diene and triene levels being significantly lower during the chick-rearing period compared with the pre-laying, early incubation, and late incubation periods. D/T ratios in livers of Adélie penguin chicks significantly changed during the $4 \mathrm{wk}$ of chick rearing (Kruskal-Wallis $\chi^{2}=9.233, \mathrm{df}=3, \mathrm{p}=$ 0.026, Fig. 5), with lower D/T ratios during the first week of chick rearing compared with the third week (pairwise Wilcoxon tests with Bonferroni corrections, $p=0.045$ ). Moreover, diene levels in livers of Adélie penguin chicks significantly differed during the first $4 \mathrm{wk}$ after hatching (Kruskal-Wallis $\chi^{2}=9.791, \mathrm{df}=3, \mathrm{p}=0.024$ ), with lower diene values in the third week compared with the first week (pairwise Wilcoxon tests with Bonferroni corrections, $p=0.028$ ). Triene levels in livers of Adélie penguin chicks did not significantly differ among the 4 wk of sampling (Kruskal-Wallis $\chi^{2}=6.902$, $\mathrm{df}=$ $3, \mathrm{p}=0.075)$.

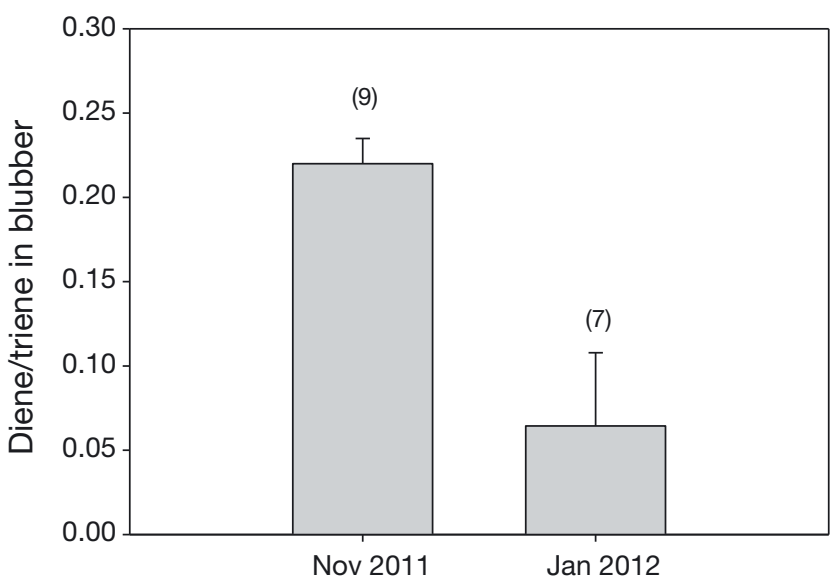

Fig. 3. Diene/triene ratio (mean $\pm \mathrm{SE}$ ) in Weddell seal blubber sampled in November 2011 ( $\mathrm{N}=9$ adult females) and in January 2012 ( $N=7$ subadults). Sample sizes are denoted by numbers in brackets 


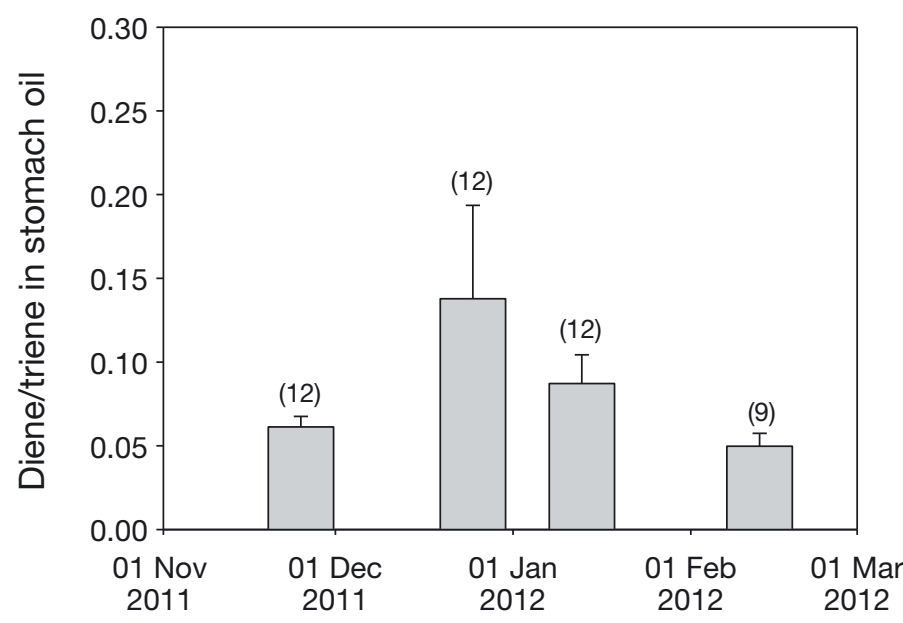

Fig. 4. Diene/triene ratio (mean $\pm \mathrm{SE}$ ) in stomach oil of snow petrels sampled during the pre-laying, early incubation, late incubation, and chick-rearing periods, respectively. Sample sizes are denoted by numbers in brackets

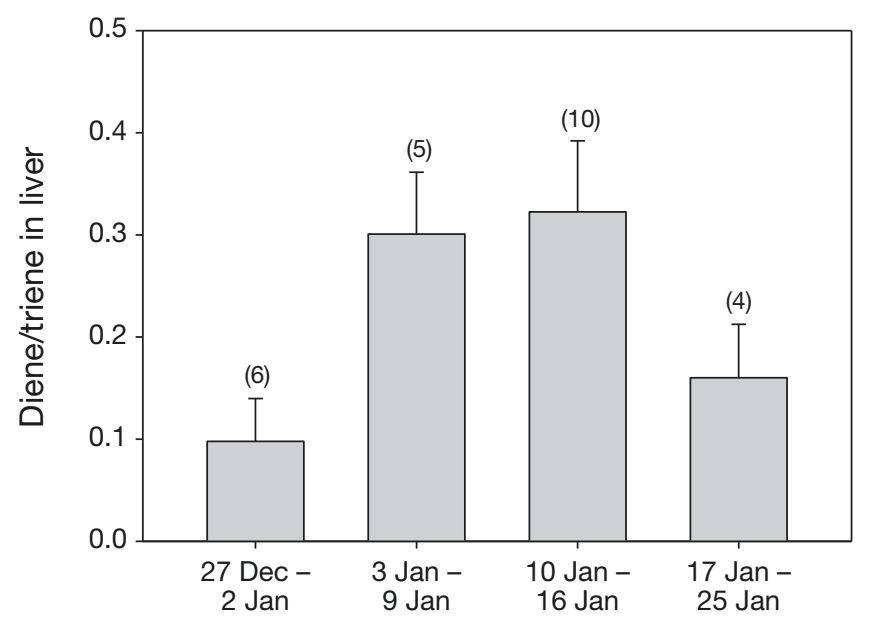

Fig. 5. Diene/triene ratios (mean $\pm \mathrm{SE}$ ) in liver of Adélie penguin chicks found dead during the first 4 wk after hatching (27 December 2011 to 02 January 2012, 03 January to 09 January 2012, 10 January to 16 January 2012, and 17 January to 25 January 2012)

\section{DISCUSSION}

\section{HBI differences between Antarctic species}

Our first goal was to investigate HBI levels in a community of seabirds and seals breeding in Adélie Land, Antarctica. Our sample size was however limited because of opportunistic sampling of unhatched eggs and dead animals in a remote environment.

Biomarkers in eggs are supposed to reflect maternal diet before and during egg formation. D/T ratios in eggs showed extremely low intraspecies varia- tions, suggesting a consistent diet in pre-laying females. The lowest $\mathrm{D} / \mathrm{T}$ ratio was detected in eggs of the cape petrel, which is consistent with consumption of krill in inshore open waters (Ridoux \& Offredo 1989). Snow petrels and Adélie penguins feed in an area covered with 20 to $80 \%$ ice (Ridoux \& Offredo 1989, Ainley et al. 1998) and rely more on ice-associated prey items than cape petrels, as confirmed by a higher D/T ratio in eggs compared with cape petrels.

The D/T ratio in liver was lower in adult Adélie penguins than in chicks. A trophic segregation between adult and chick Adélie penguins has been previously highlighted by stable isotope analyses (Cherel 2008): adult chick-rearing Adélie penguins have lower blood $\delta^{15} \mathrm{~N}$ values than chicks, indicating that adults feed for themselves on lower-trophiclevel prey and feed their chicks with higher-trophiclevel prey (Cherel 2008). By analyzing stomach contents, it has been shown that the food of Adélie penguin chicks is primarily composed of krill and fish, especially Pleuragramma antarcticum, whereas the food of adults consists mainly of euphausiids (Ainley et al. 1998, Cherel 2008). The present study corroborates this partial trophic segregation between adults and chicks, by highlighting that the diet of Adélie penguin chicks is more associated with sea ice than that of adults. The D/T ratio was lower in liver of adult Adélie penguins than in adult south polar skuas, but did not differ between Adélie penguin chicks and adult south polar skuas. This result is consistent with stomach content analyses, which revealed that adult south polar skuas rely extensively on Adélie penguin chicks during the summer breeding season in Adélie Land (Ridoux \& Offredo 1989). Hence, south polar skuas are more associated with sea-ice-derived carbon sources than adult Adélie penguins.

\section{HBI differences between Antarctic and sub-Antarctic petrels}

Our second aim was to compare HBI levels between sub-Antarctic and Antarctic seabirds during the same period. Stomach oil gives information on petrels' diet during the few days before sampling (Connan et al. 2008). D/T ratios and diene levels were higher in snow petrels that forage exclusively among ice floes in high-Antarctic waters (Ridoux \& Offredo 1989), compared with blue petrels. The D/T ratio in this sub-Antarctic seabird was close to zero and triene levels were higher than in Antarctic seabirds, confirming that they rely mostly on pelagic 
prey. Adult blue petrels use a dual foraging strategy during the chick-rearing period, by alternating short trips in the vicinity of Kerguelen Islands with long trips to Antarctic waters (Cherel et al. 2002). Stomach oil in blue petrels is only produced after long trips (Cherel et al. 2002) and is of myctophid origin, as revealed by fatty acid analyses (Connan et al. 2008). HBI levels are thus consistent with the fact that blue petrels are much less dependent on ice-associated prey items than snow petrels.

\section{HBI variation during the breeding season}

Our third aim was to describe changes in HBI levels during the breeding season. We predicted temporal changes in the $\mathrm{D} / \mathrm{T}$ ratio, as a marker of a switch in food source from ice-derived to pelagic organic matter after sea-ice retreat (Arrigo et al. 1997, Lizotte 2001). D/T ratios in blubber biopsy samples of Weddell seals were higher in November than in January. It has to be noted that the fulldepth blubber samples were analyzed for HBIs and not the outer and inner layers separately, which could have scrambled diet information. Moreover, it should be made clear that nothing is known regarding the mechanisms of HBI incorporation into tissues, including assimilation, metabolic, and elimination rates. The difference in $\mathrm{D} / \mathrm{T}$ ratios is explained by a stronger decrease in diene levels compared with triene levels between November and January. This seasonal decline in diene levels could be attributed to the ice melting and the end of sea-ice diatom proliferation from November to January. Our results could thus suggest that seals were less dependent on ice-derived organic matter in January compared with November. Another non-mutually exclusive explanation is a difference in foraging habit and diet between adult females sampled in November and subadults sampled in January. A recent study has demonstrated that females at Dumont d'Urville spend the winter pre-breeding period foraging over the shelf in heavy sea ice, at a moderate distance from the coast (Heerah et al. 2013). As females haul out in September and October to give birth and do not forage during 3 to $4 \mathrm{wk}$ postpartum (Siniff et al. 2008), HBI markers in blubber may thus reflect their stored energy reserves and thus their close association with sea ice during energy acquisition and accumulation.

The D/T ratios in stomach oil of snow petrels did not significantly differ between the 4 breeding stages, but tended to increase between the pre-laying and incubation periods, and then decrease between the incubation and chick-rearing periods. This seasonal trend could have been attenuated by the fact that snow petrel forage almost exclusively in pack-ice areas (Ridoux \& Offredo 1989), even after the seasonal ice retreat. In the liver of Adélie penguin chicks, the D/T ratios were lower in late December compared with mid-January. These seasonal changes in HBI levels provided further evidence that the diet of Adélie penguins is closely dependent on sea-ice changes (Ainley et al. 1998) and that foraging patterns vary with the course of the breeding season (Lyver et al. 2010). Indeed, distance and duration of breeders' foraging trips increase between the guard and crèche stages, and the abundance of fish relative to Antarctic krill increases in the chick meal composition (Lyver et al. 2010). Seasonal changes in HBI levels suggest that Adélie penguins rely more on ice algal-derived organic matter to feed their chicks in mid-January compared with late December.

In the context of climate change, the use of HBIs may shed new light on the repercussions of changing sea ice on the life-history traits and population dynamics of Antarctic seals and seabirds.

Acknowledgements. This work was funded by the European Research Council (ICEPROXY, project number 203441) and was logistically supported by the French Institute PaulEmile Victor (IPEV project number 1010, G. Massé; 109, H. Weimerskirch). We thank C. Blanc for her help as a veterinary surgeon, A. M. Thierry for collecting samples in the field, and C. Robineau and V. Klein for their excellent technical assistance in lipid purification. We thank the reviewers for their constructive comments on the manuscript.

\section{LITERATURE CITED}

Ainley DG, Wilson PR, Barton KR, Ballard G, Nur N, Karl B (1998) Diet and foraging effort of Adélie penguins in relation to pack-ice conditions in the southern Ross Sea. Polar Biol 20:311-319

Arrigo KR, Lizotte MP, Worthen DL, Dixon P, Dieckmann G (1997) Primary production in Antarctic sea ice. Science 276:394-397

Barbraud C, Weimerskirch H (2001) Contrasting effects of the extent of sea-ice on the breeding performance of an Antarctic top predator, the snow petrel Pagodroma nivea. J Avian Biol 32:297-302

Belt ST, Massé G, Rowland SJ, Poulin M, Michel C, LeBlanc B (2007) A novel chemical fossil of palaeo sea ice: $\mathrm{IP}_{25}$. Org Geochem 38:16-27

Brown TA, Belt ST (2012a) Identification of the sea ice diatom biomarker $\mathrm{IP}_{25}$ in Arctic benthic macrofauna: direct evidence for a sea ice diatom diet in Arctic heterotrophs. Polar Biol 35:131-137

Brown TA, Belt ST (2012b) Closely linked sea ice-pelagic coupling in the Amundsen Gulf revealed by the sea ice diatom biomarker $\mathrm{IP}_{25}$. J Plankton Res 34:647-654 
Brown TA, Belt ST, Ferguson SH, Yurkowski DJ, Davison NJ, Barnett JEF, Jepson PD (2013a) Identification of the sea ice diatom biomarker $\mathrm{IP}_{25}$ and related lipids in marine mammals: a potential method for investigating regional variations in dietary sources within higher trophic level marine systems. J Exp Mar Biol Ecol 441: 99-104

Brown TA, Bicknell AWJ, Votier SC, Belt ST (2013b) Novel molecular fingerprinting of marine avian diet provides a tool for gaining insights into feeding ecology. Environ Chem Lett 11:283-288

> Cherel Y (2008) Isotopic niches of emperor and Adélie penguins in Adélie Land, Antarctica. Mar Biol 154:813-821

Cherel Y, Bocher P, Trouvé C, Weimerskirch H (2002) Diet and feeding ecology of blue petrels Halobaena caerulea at Iles Kerguelen, Southern Indian Ocean. Mar Ecol Prog Ser 228:283-299

Connan M, Mayzaud P, Trouvé C, Barbraud C, Cherel Y (2008) Interannual dietary changes and demographic consequences in breeding blue petrels from Kerguelen Islands. Mar Ecol Prog Ser 373:123-135

Forcada J, Trathan PN, Boveng PL, Boyd IL and others (2012) Responses of Antarctic pack-ice seals to environmental change and increasing krill fishing. Biol Conserv 149:40-60

Giraldo C, Cherel Y, Vallet C, Mayzaud P and others (2011) Ontogenic changes in the feeding ecology of the early life stages of the Antarctic silverfish (Pleuragramma antarcticum) documented by stable isotopes and diet analysis in the Dumont D'Urville Sea (East Antarctica). Polar Sci 5:252-263

Goutte A, Cherel Y, Houssais MN, Klein V and others (2013) Diatom-specific highly branched isoprenoids as biomarkers in Antarctic consumers. PLoS ONE 8:e56504

Goutte A, Cherel Y, Ozouf-Costaz C, Robineau C, Lanshere J, Massé G (2014) Contribution of sea ice organic matter in the diet of Antarctic fishes: a diatom-specific highly branched isoprenoid approach. Polar Biol 37:903-910

Editorial responsibility: Scott Shaffer,

San Jose, California, USA
Heerah K, Andrews-Goff V, Williams GD, Sultan E, Hindell MA, Patterson T, Charrassin JB (2013) Ecology of Weddell seals during winter: influence of environmental parameters on their foraging behaviour. Deep-Sea Res II: 88-89:23-33

La Mesa M, Eastman JT (2012) Antarctic silverfish: life strategies of a key species in the high-Antarctic ecosystem. Fish Fish 13:241-266

Lizotte MP (2001) The contributions of sea ice algae to Antarctic marine primary production. Am Zool 41:57-73

Lyver PO'B, MacLeod CJ, Ballard G, Karl BJ and others (2010) Intra-seasonal variation in foraging behavior among Adélie penguins (Pygocelis adeliae) breeding at Cape Hallett, Ross Sea, Antarctica. Polar Biol 34:49-67

Massé G, Belt ST, Crosta X, Schmidt S, Snape I, Thomas DN, Rowland SJ (2011) Highly branched isoprenoids as proxies for variable sea ice conditions in the Southern Ocean. Antarct Sci 23:487-498

Nicol S (2006) Krill, currents, and sea ice: Euphausia superba and its changing environment. Bioscience 56:111-120

Quetin LB, Ross RM (2001) Environmental variability and its impact on the reproductive cycle of Antarctic krill. Am Zool 41:74-89

R Development Core Team (2012) R: A language and environment for statistical computing. R Foundation for Statistical Computing, Vienna. Available at www.r-project .org

> Ridoux V, Offredo C (1989) The diets of five summer breeding seabirds in Adélie Land, Antarctica. Polar Biol 9: 137-145

Siniff DB, Garrott RA, Rotella JJ, Fraser WR, Ainley DG (2008) Projecting the effects of environmental change on Antarctic Seals. Antarct Sci 20:425-435

Sinninghe Damsté S, Rijpstra WIP, Coolen MJL, Schouten S, Volkman JK (2007) Rapid sulphurisation of highly branched isoprenoid (HBI) alkenes in sulphidic Holocene sediments from Ellis Fjord, Antarctica. Org Geochem 38: 128-139

Submitted: January 31, 2014; Accepted: July 24, 2014

Proofs received from author(s): September 17, 2014 